\title{
Predicting Upwelling Radiance on the West Florida Shelf
}

\author{
W. Paul Bissett \\ Florida Environmental Research Institute \\ 10500 University Center Dr. \\ Suite 140 \\ Tampa, FL USA 33612 \\ phone: (813) 837-3374 x102 fax: (813) 902-9758 email: pbissett@feriweb.org \\ Award Number: N00014-01-1-0456 \\ http://www.feriweb.org
}

\section{LONG-TERM GOALS}

The prediction of inherent optical properties [IOPs] and water-leaving radiance $\left[\mathrm{L}_{\mathrm{w}}\right]$ in coastal waters over a 5 to 10 day time horizon will require a numerical simulation that accurately forecasts the physical, ecological, and optical environment. Critical to the ecological and optical forecast is the ability to directly compare the water-leaving radiance field to those being collected by aircraft and satellite platforms. Our goal is to develop the ecological and optical models and computer codes to initialize, validate, and predict the IOPs and $\mathrm{L}_{\mathrm{w}}$ over an operational time horizon.

\section{OBJECTIVES}

1) Couple EcoSim 2.0 to a robust radiative transfer model to yield water-leaving radiance for a given IOP distribution

2) Initialize and validate spectral water-leaving radiance with remote sensing data.

3) Couple EcoSim 2.0 to the Regional Ocean Modeling System (ROMS)

\section{APPROACH}

The pace of development of prognostic ecological/optical data and modeling systems has greatly accelerated in recent years such that we can now reasonably discuss the likelihood of predicting red tides, and concomitant impacts on water clarity on the West Florida Shelf(WFS). Accurate prediction of water clarity and color suggests a fundamental knowledge of marine ecological systems, and the validation of such data and modeling systems would provide characterization of the littoral environment over operational time horizons. Water clarity and color are directly dependent on the IOPs of the water column and the modeling component of these prognostic systems requires a fundamental set of equations that describe the interactions between the production and destruction of the IOPs. As the IOPs of absorption, scattering, and the scattering phase function can be described by a summation of the individual components, the cycle of color can be described by equations representing the individual active color constituents, i.e., phytoplankton, organic detritus, Colored Dissolved Organic Matter (CDOM), sediments, bathymetry, and bottom classification. The description of the cycling of each component allows for feedback effects between the in-water light field and the production and destruction of color. 


\section{Report Documentation Page}

Form Approved

OMB No. 0704-0188

Public reporting burden for the collection of information is estimated to average 1 hour per response, including the time for reviewing instructions, searching existing data sources, gathering and maintaining the data needed, and completing and reviewing the collection of information. Send comments regarding this burden estimate or any other aspect of this collection of information,

including suggestions for reducing this burden, to Washington Headquarters Services, Directorate for Information Operations and Reports, 1215 Jefferson Davis Highway, Suite 1204, Arlington

VA 22202-4302. Respondents should be aware that notwithstanding any other provision of law, no person shall be subject to a penalty for failing to comply with a collection of information if it

does not display a currently valid OMB control number.

1. REPORT DATE

30 SEP 2006

4. TITLE AND SUBTITLE

Predicting Upwelling Radiance on the West Florida Shelf

6. $\operatorname{AUTHOR}(\mathrm{S})$

7. PERFORMING ORGANIZATION NAME(S) AND ADDRESS(ES)

Florida Environmental Research Institute,10500 University Center Dr. Suite 140,Tampa,FL,33612

9. SPONSORING/MONITORING AGENCY NAME(S) AND ADDRESS(ES)

3. DATES COVERED

00-00-2006 to 00-00-2006

5a. CONTRACT NUMBER

5b. GRANT NUMBER

5c. PROGRAM ELEMENT NUMBER

5d. PROJECT NUMBER

5e. TASK NUMBER

5f. WORK UNIT NUMBER

8. PERFORMING ORGANIZATION REPORT NUMBER

10. SPONSOR/MONITOR'S ACRONYM(S)

11. SPONSOR/MONITOR'S REPORT NUMBER(S)

12. DISTRIBUTION/AVAILABILITY STATEMENT

Approved for public release; distribution unlimited

13. SUPPLEMENTARY NOTES

14. ABSTRACT

15. SUBJECT TERMS

16. SECURITY CLASSIFICATION OF:

a. REPORT

unclassified b. ABSTRACT

unclassified c. THIS PAGE

unclassified
17. LIMITATION OF ABSTRACT

Same as

Report (SAR)
18. NUMBER 19a. NAME OF

OF PAGES RESPONSIBLE PERSON

6

Standard Form 298 (Rev. 8-98) Prescribed by ANSI Std Z39-1 
The marine optical environment may change at the same time scale of weather change, so any operational prognostic optical system would need to be embedded into a larger system of data collection and numerical modeling. Such a system would use moorings, ships, Autonomous Underwater Vehicles (AUVs), satellites, and physical/ecological/optical numerical models to provide integrated data streams to a wide community of users. The systems would need to be able to assimilate data as it became available, and provide forecasts over a wide range of time and space scales. The West Florida Shelf (WFS) is an ideal location to help develop these nowcast/forecast systems, in part due to a large number of other research programs focused on the WFS, including other ONR funded technology programs, NOAA/EPA ECOlogy of Harmful Algal Blooms (ECOHAB) program, and the State of Florida Coastal Ocean Monitoring and Prediction System (COMPS) program. The ECOHAB and COMPS programs are focused on time scales ranging from months to years and spatial scales ranging from kilometers to $1000 \mathrm{~s}$ of kilometers. Therefore, this site provides a natural location to develop broad scale time and space models of the inherent optical properties.

The WFS is unique in other ways that make it ideal for the development of forecasting systems. In particular, the variance in color and clarity of the near-shore waters is extreme, ranging from oligotrophic Case 1-type waters to highly attenuating Case 2 waters (Bissett et al., 1997; Carder and Steward, 1985; Carder et al., 1989). The low-nutrient and low-colored waters of the WFS are derived from the oligotrophic waters of the central Gulf of Mexico and the waters of the Caribbean Sea via the Loop Current. These waters have typical open ocean color signals. In the deeper waters off the shelf, the variations in surface color are driven by seasonal nutrients and CDOM introductions via deep mixing, as well as eddy fluxes, much like the classic understanding of Case 1 ocean color. As one moves across the shelf break onto the outer shelf, complications to the classic blue ocean signal arise from both Loop Current intrusions that bring higher nutrient waters (and CDOM) into the euphotic zone and river CDOM fluxes from the Mississippi, Mobile, and Apalachicola Rivers. In the inner shelf, the color signal becomes even more complicated as the introduction of waters from Suwannee, Hillsborough, Peace, and Caloosahatchee Rivers mix with the above water masses, as well as with those waters created locally from high energy mixing (waves, long-shore currents, etc.) and heat flux imbalances.

The ecological/optical conditions on the WFS are as complicated as any coastal region, yielding situations where the chlorophyll a biomass may range from 0.01 to $>20 \mu \mathrm{g} \mathrm{liter}^{-1}$ at the same location during different time periods. When oligotrophic waters dominant the shelf, bottom features are clearly evident in high-resolution hyperspectral data to a depth of 30 meters. At other times, river and estuary waters dominate, and the bottom is undistinguishable in waters $<2$ meters deep. In between these two conditions, the color signal is mainly a function of the ecological interactions between phytoplankton growth and loss and CDOM creation and destruction. Within the inner shelf, the color signal is further modified by the bottom classification and sediment re-suspension. Our goal on the WFS is to derive and validate a set of fundamental ecological/optical/physical equations that addresses, and eventually predicts, the complexity of the IOPs and the resultant water-leaving radiance. This site is an ideal location for the regional time and space scales being studied.

\section{WORK COMPLETED}

This year marked the closing months of this grant; please see the final report for the full description of work accomplished during the grant. During this period we focused on the integration of Ecolight into a run-time version of the EcoSim code. C. Mobley and L. Sundman decided to pursue this inline 
coupling of the codes in a PC development environment, outside of the ROMS development loop. This was primarily due to the 1) difficulties we had experienced with coding ROMS subroutines, 2) the ease of code development and results visualization in a PC environment, and 3) their expertise on this platform. Our role was to help facilitate this code development by providing a compiled version of the EcoSim/ROMS code outside of the C-preprocessor used for UNIX machines, specifically for the BioToy version (6 x 6 grid version). We also provided support for debugging and error checking. We continue to help this effort on other (NSF) funding.

\section{IMPACT/APPLICATIONS}

Forecasting IOPs over operational time horizons of 5 to 10 days will require the ability to directly compare predictions of water-leaving radiance to the data most likely to be used for initialization and validation of the predictions, i.e., aircraft and satellite hyperspectral remote sensing data. This effort will yield a simulation ready to begin direct data assimilation of the water column optical properties to predict absorption and scattering over short-term time horizons.

\section{TRANSITIONS}

The EcoSim 2.0 model has been transitioned as part of the open source code of the ONR ROMS/TOMS code set. It is being used by Rutgers University in their current MURI program.

\section{RELATED PROJECTS}

We are also collaborating with Dr. C. Mobley of Sequoia Scientific, Inc for the coupling of EcoSim with Hydrolight (N00014D01610002), and Drs. R. Arnone, NRL, and K. Carder, USF, for satellite data analysis.

\section{REFERENCES}

Bissett, W.P., Arnone, R., DeBra, S., Dieterle, D., Dye, D., Kirkpatrick, G., Schofield, O. and Vargo, G., 2005. Predicting the optical properties of the West Florida Shelf: resolving the potential impacts of a terrestrial boundary condition on the distribution of colored dissolved and particulate matter. Marine Chemistry, 95: 199-233.

Bissett, W.P., Arnone, R., DeBra, S., Dye, D., Kirkpatrick, G., Mobley, C. and Schofield, O.M., 2005. The Integration Of Ocean Color Remote Sensing With Coastal Nowcast/Forecast Simulations Of Harmful Algal Blooms (HABs). In: M. Babin, J. Cullen and R. Roesler (Editors), MANUAL ON HARMFUL MARINE MICROALGAE. UNESCO MONOGRAPHS ON OCEANOGRAPHIC METHODOLOGY, pp. (in press).

Bissett, W.P., Carder, K.L., Walsh, J.J. and Dieterle, D.A., 1999. Carbon cycling in the upper waters of the Sargasso Sea: II. Numerical simulation of apparent and inherent optical properties. Deep-Sea Research I, 46(2): 271-317.

Bissett, W.P., Walsh, J.J., Dieterle, D.A. and Carder, K.L., 1999. Carbon cycling in the upper waters of the Sargasso Sea: I. Numerical simulation of differential carbon and nitrogen fluxes. Deep-Sea Research I, 46(2): 205-269. 
Gregg, W.W. and Carder, K.L., 1990. A simple spectral solar irradiance model for cloudless maritime atmospheres. Limnology and Oceanography, 35(8): 1657-1675.

Morel, A. and Maritorena, S., 2001. Bio-Optical properties of oceanic waters: A reapprasial. Journal of Geophysical Research, 106(C4): 7163-7180.

\section{PUBLICATIONS}

Bissett, W. P., Arnone, R., DeBra, S., Dye, D., Kirkpatrick, G., Mobley, C., and Schofield, O.M. (2005). The Integration Of Ocean Color Remote Sensing With Coastal Nowcast/Forecast Simulations Of Harmful Algal Blooms (HABs). UNESCO Monographs on Oceanographic Methodology- Manual on Harmful Marine Microalgae, UNESCO [submitted, refereed].

Mobley, C. D., L. K. Sundman, C. O. Davis, T. V. Downes, R. A. Leathers, M. J. Montes, J. H. Bowles, W. P. Bissett, D. D. R. Kohler, R. P. Reid, E. M. Louchard, and A. Gleason, 2005. Interpretation of hyperspectral remote-sensing imagery via spectrum matching and look-up tables. Applied Optics 44(17), 3576-3592. [published, refereed]

Schofield, O., Bosch, J., Glenn, S., Kirkpatrick, G., Kerfoot, J., Moline, M., Oliver, M., and Bissett, P. (2005). Harmful Algal Blooms in a Dynamic Environment: How Can Optics Help The Field-Going and Sample-Poor Biologist? UNESCO Monographs on Oceanographic Methodology- Manual on Harmful Marine Microalgae, UNESCO [submitted, refereed].

Bissett, W.P., Arnone, R., DeBra, S., Deterlie, D., Dye, D., Kirkpatrick, G., Schofield, O. and Walsh, J. (2005). Predicting the Inherent Optical Properties and Colored Dissolved Organic Matter Dynamics on the West Florida Shelf. Marine Chemistry, 95, 199-233, [published, refereed].

Glenn, S., Arnone, R., Bergman, T., Bissett, P., Crowley, M., Cullen, J., Gryzmski, J., Haidvogel, D., Kohut, J., Moline, M., Oliver, M., Orrico, C., Sherrell, R., Song, T., Weidemann, A., Chant, R. and Schofield, O., 2004. The Biogeochemical Impact of Summertime Coastal Upwelling on the New Jersey Shelf. Journal of Geophysical Research: 109 (C12S04), [published, refereed].

Chen, R.F., Bissett, W.P., Coble, P., Conmy, R., G. Gardner, B., Moran, M.A., Wang, X., Wells, M.L., Whelan, P. and Zepp, R.G. (2004). Chromophoric Dissolved Organic Matter (CDOM) Source Characterization in the Louisiana Bight. Marine Chemistry, 89(1-4): 257-272, [published, refereed].

Kohler, D.D.R., Bissett, W.P., Steward, R.G. and Davis, C.O., 2004. A New Approach for the Radiometric Calibration of Spectral Imaging Systems. Optics Express, 12(11), [published, refereed].

Mobley, C.D., Stramski, D., Bissett, W.P. and Boss, E., 2004. Optical modeling of ocean waters: Is the Case 1 - Case 2 classification still useful? Oceanography, 17(2): 60-67, [published, refereed].

Oliver, M.J., Kohut, J.T., Irwin, A.J.G., Schofield, O.M., Glenn, S., Moline, M.A., and Bissett, W.P. (2004). Bioinformatic Approaches for Objective Detection of Water Masses. Journal of Geophysical Research, 109(C7): 12, [published, refereed]. 
Philpot, W.D., Davis, C.O., Bissett, W.P., Mobley, C., Kohler, D.D.R., Lee, Z.P., Snyder, W., Steward, R.G., Gould, R. and Arnone, R., 2004. Bottom characterization from hyperspectral image data. Oceanography, 17(2): 76-85, [published, refereed].

Schofield, O., Arnone, R., Bissett, P., Dickey, T., Davis, C., Finkel, Z., Oliver, M. and Moline, M., 2004. Watercolors in the coastal zone: what can we see? Oceanography, 17(2): 24-31, [published, refereed].

Schofield, O., Bergmann, T., Oliver, M., Moline, M., and Bissett, P. (2004). Inversion of the Bulk Absorption in the Mid-Atlantic Bight and its Utility for Water Mass Analysis in Optically Complex Coastal Waters. Journal of Geophysical Research, 190(C12S04): 12 [published, refereed].

Schofield, O., Bissett, W. P., Frazer, T.K., Iglesias-Rodriguez, D., Moline, M.A., Glenn, S. (2003). Development of Regional Coastal Ocean Observatories and the Potential Benefits to Marine Sanctuaries, Marine Technology Society Journal, 37 (1): 54-67, [published, refereed].

Shulman, I., Haddock, S.H.D., McGillicuddy, D.J.Jr., D. Paduan, J.D., Bissett, W.P. (2003). Numerical Modeling of Bioluminescence Distributions in the Coastal Ocean. Journal of Atmospheric and Oceanic Technology 20 (7):1060-1068, [published, refereed].

Zhang, X., Lewis, M., Bissett, P. and Johnson, B. (2004) Optical Influence of Ship Wakes. Applied Optics, 43(15): 3122-3132, [published, refereed].

Davis, C. O., Bissett, W. P., Brown, C. (2003). Optical remote sensing of the coastal ocean: Future directions for observing and monitoring, Earth System Monitor, Vol. 13, No. 2, [published].

Davis, C. O., J. Bowles, R. A. Leathers, D. Korwan, T. V. Downes, W. A. Snyder, W. J. Rhea, W. Chen, J. Fisher, W. P. Bissett and R. A. Reisse (2002). Ocean PHILLS hyperspectral imager: design, characterization, and calibration, Optics Express, 10(4): 210-221, [published, refereed].

Schofield, O., Bergmann, T., Bissett, W. P., Grassle, F., Haidvogel, D., Kohut, J., Moline, M., Glenn, S. (2002). Linking regional coastal observatories to provide the foundation for a national ocean observation network. Journal of Oceanic Engineering, 27(2): 146-154, [published, refereed].

Schofield, O., Glenn, S., Chant, R., Moline, M. A., Bissett, P., Haidvogel, D., and Wilkins, J. (2002). The evolution of a nearshore coastal observatory and the establishment of the New Jersey Shelf Observing System. Oceanology International 2002, [published].

Walsh J.J., Haddad, K.D., Dieterle, D.A., Weisberg, R.H., Li, Z., Yang, H., Muller-Karger, F.E., Heil, C.A., and Bissett, W.P., (2002). A numerical analysis of landfall of the 1979 red tide of Karenia brevis along the west coast of Florida. Continental Shelf Research, 22(1):15-38, [published, refereed].

Bissett, W. P, Schofield, O., Glenn, S., Cullen, J. J., Miller, W. L., Plueddemann, A. J., Mobley, C. D., (2001). Resolving the impacts and feedbacks of ocean optics on upper ocean ecology. Oceanography, 14:30-49, [published, refereed].

Walsh, J.J., B. Penta, D.A. Dieterle, and W. P. Bissett. (2001). Predictive ecological modeling of harmful algal blooms. Human Ecological Risk Assessment, 7:1369-1383, [published, refereed]. 
Bissett, W.P., Schofield, O., Mobley, C., Crowley, M.F., and Moline, M.A. (2000). Optical Remote Sensing Techniques in Biological Oceanography. Methods in Microbiology, Volume 30: Marine Microbiology (J.H. Paul, ed), Academic Press, London. 519-540, [published, refereed].

Bissett, W. P., J. J. Walsh, D. A. Dieterle and K. L. Carder (1999). Carbon cycling in the upper waters of the Sargasso Sea: I. Numerical simulation of differential carbon and nitrogen fluxes. Deep-Sea Research, 46(2):205-269, [published, refereed].

Bissett, W. P., K. L. Carder, J. J. Walsh and D. A. Dieterle (1999). Carbon cycling in the upper waters of the Sargasso Sea: II. Numerical simulation of apparent and inherent optical properties. Deep-Sea Research, 46(2):271-317, [published, refereed].

Schofield, O., Grzymski, J., Bissett, W.P., Kirkpatrick, G., Millie, D.F., Moline, M., and Roesler, C.S. (1999). Optical monitoring and forecasting systems for harmful algal blooms: possibility or pipe dream? Journal of Phycology, 35, 1477-1496, [published, refereed].

Walsh, J.J., D. A. Dieterle, F. E. Muller-Karger, R. Bohrer, W. P. Bissett, R. J. Varela, R. Aparicio, R. Diaz, R. Thunell, G. T. Taylor, M. I. Scranton, K. A. Fanning, and E. T. Peltzer (1999). Simulation of carbon-nitrogen cycling during spring upwelling in the Cariaco Basin. Journal of Geophysical Research, 104, 7807-7825, [published, refereed].

\section{HONORS/AWARDS/PRIZES}

Semi-Finalist, 2003 Small Business of the Year, Florida Environmental Research Institute, W. Paul Bissett, Ph.D., Executive Director, Greater Tampa Chamber of Commerce.

Finalist, 2004 Small Business of the Year, Florida Environmental Research Institute, W. Paul Bissett, Ph.D., Executive Director, Greater Tampa Chamber of Commerce. 